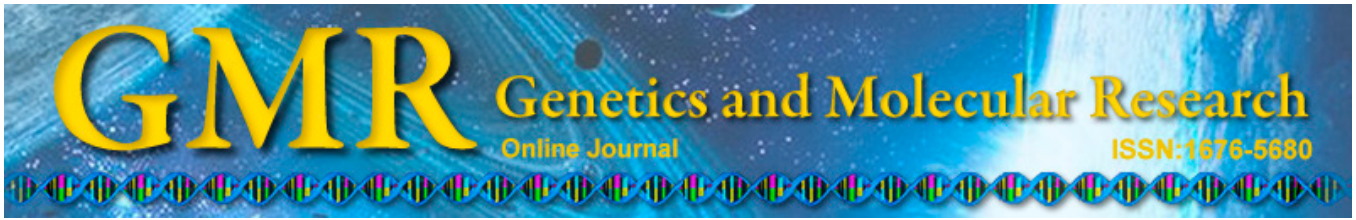

\title{
Anticancer activity of Bombyx batryticatus ethanol extract against the human tumor cell line HeLa
}

\author{
W.P. Wu, J. Cao, J.Y. Wu, H. Chen and D. Wang \\ Institute of Entomology, Northwest A\&F University, Yangling, Shaanxi, China \\ Corresponding author: D. Wang \\ E-mail: wanghande@yahoo.com
}

Genet. Mol. Res. 14 (1): 79-88 (2015)

Received November 26, 2013

Accepted March 11, 2014

Published January 15, 2015

DOI http://dx.doi.org/10.4238/2015.January.15.10

\begin{abstract}
Anticancer activity of Bombyx batryticatus ethanol extract (BBE) against HeLa cells was studied using cell viability, DNA fragmentation, real-time polymerase chain reaction, and Western blot analyses. The BBE inhibited the growth and induced apoptosis of HeLa cells. The MTT assay indicated that the BBE induced cytotoxicity in $\mathrm{HeLa}$ cells in a time- and concentration-dependent manner. When HeLa cells were treated for $48 \mathrm{~h}$, the $50 \%$ inhibitory concentration $\left(\mathrm{IC}_{50}\right)$ value for the BBE was $1.564 \mathrm{mg} / \mathrm{mL}$. The microscopy results showed that HeLa cells were severely distorted and showed slow growth; some cells became round in shape when treated with $5 \mathrm{mg} / \mathrm{mL} \mathrm{BBE}$ for $24 \mathrm{~h}$. The DNA ladder results revealed excessive DNA fragmentation in HeLa cells treated with $7 \mathrm{mg} / \mathrm{mL}$ BBE for $36 \mathrm{~h}$. The proapoptotic activity of the BBE was attributed to its ability to modulate the expression of $B c l-2$ and Bax genes. The mRNA and protein expression levels of Bax were remarkably higher whereas those of $B c l-2$ were lower than those in the control cells; this led to an increased $\mathrm{Bax} / \mathrm{Bcl}-2$ ratio in cells treated with the BBE for $36 \mathrm{~h}$. The results suggest that the BBE might play an important role in tumor growth suppression by inducing apoptosis in
\end{abstract}


human cervical cancer cells via the regulation of the Bcl-2- and Baxmediated apoptotic pathways.

Key words: Bombyx batryticatus; Apoptosis; Cytotoxicity; HeLa cells; Apoptotic pathway

\section{INTRODUCTION}

Traditional herbal medicines are widely used globally and are being increasingly used in developed countries ( $\mathrm{Li}$ et al., 2009). In developing countries, traditional medicines have become popular mainly because of the long unsustainable economic situation in these countries, high costs and undesirable adverse effects of synthetic drugs, and an increase in drug resistance to common diseases (Fokunang et al., 2011). In recent decades, Chinese herbal medicines have been shown to have the ability to inhibit growth and induce apoptosis in different cancer cells. Huanglian is a traditional Chinese herb, the extract of which strongly inhibited cell growth by suppressing the expression of cyclin B1 and inhibiting the activity of CDC2 kinase in human cancer cells (Li et al., 2000). Long-dan-tang (a Chinese herbal formula) had remarkable cytotoxic effects on human hepatoma Hep3B cells (Chou et al., 2003). The water extract of DaHuang exerted potential anticancer activity by inhibiting growth and inducing apoptosis of MCF-7 and A549 cell lines (Li et al., 2009). Flavonoids from Chinese herbal medicines have been shown to induce apoptosis in human hepatocarcinoma SMMC-7721 cells in vitro (Hu et al., 2009). Therefore, traditional medicines can have therapeutic value for the treatment of cancer.

Bombyx batryticatus is the dried larva of Bombyx mori L. (silkworm) infected by Beauveria bassiana (Bals.) Vuill. It is a traditional Chinese medicine that was first described in an ancient Chinese medicine magnum opus named "The Divine Farmer's Materia Medica" (written in B.C. 221). Traditionally used for dispelling flatulence, relieving fever, dissolving phlegm, and reducing spasms, the ethanol extract of B. batryticatus (BBE) exerted significant toxic effects on cotton bollworm, Helicoverpa armigera, and inhibited the activity of alkaline phosphatase (Cao et al., 2012). However, whether the BBE has any effect on human cancer cells remains unknown. In this study, we evaluated the effects of BBE on human cervical cancer cells (HeLa) using the 3-(4,5-dimethylthiazol-2-yl)-2,5-diphenyltetrazolium bromide (MTT) assay and by conducting cell apoptosis and expression analyses of cell cycle regulatory genes. To our knowledge, this is the first report on the anticancer activity of BBE in vitro.

\section{MATERIAL AND METHODS}

\section{Preparation of BBE from Bombyx batryticatus}

BBE is a compound derived by extraction from dried B. batryticatus. B. batryticatus was purchased from Xi'an Chinese Medicine Co. Ltd. (Xi'an, China). The B. batryticatus were oven dried at $60^{\circ} \mathrm{C}$ for $10 \mathrm{~h}$ and then ground to a 60 -mesh powder for extraction. One kilogram of B. batryticatus powder was extracted for $12 \mathrm{~h}$ with $1 \mathrm{~L} 95 \%$ ethanol at room temperature; the extraction process was repeated three times. The samples were filtered after each extraction, and the ethanol extract was collected. Leach liquor was removed from the 
combined extract using a vacuum rotary evaporator. Extract $(50 \mathrm{~g})$ was dissolved in $500 \mathrm{~mL}$ distilled water and extracted with $500 \mathrm{~mL}$ petroleum ether to remove any grease residues. The aqueous phase was transferred to a vacuum rotary evaporator to evaporate the water, and the mass of the extract was determined. The extract was finally dissolved in RPMI-1640 medium without fetal calf serum (FBS) to a concentration of $100 \mathrm{mg} / \mathrm{mL}(\mathrm{w} / \mathrm{v})$ and stored at $-20^{\circ} \mathrm{C}$ before use.

\section{Cell line and cell culture}

Human cervical cancer cell line, HeLa was provided by the Medical School of Xi'an Jiaotong University (Xi'an, China). Cells were cultured in RPMI-1640 medium (Hyclone, USA) supplemented with 10\% heat-inactivated calf serum (Hyclone, USA), $100 \mu \mathrm{g} / \mathrm{mL}$ penicillin (w/v), and $50 \mu \mathrm{g} / \mathrm{mL}$ streptomycin in an incubator (HF90; Heal Force Bio-Meditech Holdings Limited, China) maintained at a water-saturated atmosphere with $5 \% \mathrm{CO}_{2}$ at $37^{\circ} \mathrm{C}$.

\section{Cell viability assay}

Cell viability was measured using the MTT assay. Cells were plated on 96-well plates at a cell density of 5000 cells per well containing $200 \mu \mathrm{L}$ RPMI-1640 and incubated under the conditions described above for $24 \mathrm{~h}$. The culture medium was replaced with fresh medium containing different concentrations $(1-10 \mathrm{mg} / \mathrm{mL}, \mathrm{w} / \mathrm{v})$ of BBE and further incubated for 24 , 48, and $72 \mathrm{~h}$. At the end of each treatment, $200 \mu \mathrm{L}$ fresh medium containing $20 \mu \mathrm{L} 5 \mathrm{mg} /$ $\mathrm{mL}$ MTT (w/v) solution was added to each well, and the 96-well plates were incubated with $5 \% \mathrm{CO}_{2}$ at $37^{\circ} \mathrm{C}$ for $4 \mathrm{~h}$. The culture medium with MTT was removed, and $150 \mu \mathrm{L}$ dimethyl sulfoxide (DMSO) was added to each well to dissolve the formazan. The absorbance was measured at $570 \mathrm{~nm}(630 \mathrm{~nm}$ as a reference) using a Tecan Infinite 200 PRO multimode microplate reader (Tecan, Switzerland). The experiments were repeated three times. Cell viability was expressed as a percentage of the values in control cultures.

\section{Cell morphological assessment}

HeLa cells were cultured in RPMI-1640 until the mid-log phase. Different concentrations of BBE $[1,3$, and $5 \mathrm{mg} / \mathrm{mL}(\mathrm{w} / \mathrm{v})]$ were added to the culture medium, and incubation was continued for an additional $24 \mathrm{~h}$. At the end of the incubation, the morphology of the cells was determined using a Nikon TE2000 inverted microscope (Nikon, Japan).

\section{DNA fragmentation assay}

BBE-induced apoptosis of HeLa cells was detected using the DNA fragmentation assay. HeLa cells $\left(5 \times 10^{5}\right)$ were treated with different concentrations of BBE $[3,4,5,6$, and 7 $\mathrm{mg} / \mathrm{mL}(\mathrm{w} / \mathrm{v})]$ for $36 \mathrm{~h}$ at $37^{\circ} \mathrm{C}$ and $5 \% \mathrm{CO}_{2}$. DNA was isolated according to the protocol of the DNA ladder detection kit (Millipore). DNA was separated on a $1.5 \%$ agarose gel, stained with ethidium bromide, and separated at $50 \mathrm{~V}$ for $2 \mathrm{~h}$ in Tris-acetate buffer, $\mathrm{pH} 8.0$, and $1 \mathrm{mM}$ ethylenediaminetetraacetic acid. DNA fragments were visualized and recorded using a Gene Genius Bioimaging System Universal Hood II (Bio-Rad, USA) after staining. 


\section{Western blot analysis}

The protein expression patterns of $\beta$-actin, Bax, and Bcl-2 in HeLa cells were detected using Western blot analysis. HeLa cells $\left(5 \times 10^{5}\right)$ were treated with 3,4 , 5, and 6 $\mathrm{mg} / \mathrm{mL}$ BBE $(\mathrm{w} / \mathrm{v})$ for $36 \mathrm{~h}$, and the cell culture dishes were placed on ice and washed twice with ice-cold phosphate buffered saline. Proteins were isolated using RIPA buffer at $4^{\circ} \mathrm{C}$ for $15 \mathrm{~min}$. Protein samples were centrifuged at $12,000 \mathrm{rpm}$ for $10 \mathrm{~min}$ at $4^{\circ} \mathrm{C}$, mixed with the sample loading buffer, and boiled for $10 \mathrm{~min}$. The protein concentration in the supernatant was determined using Bio-Rad protein assay reagent (Bio-Rad, USA). Equal amounts of protein lysates were separated by electrophoresis on a $15 \%$ sodium dodecyl sulfate-polyacrylamide gel and transferred onto polyvinylidene fluoride (PVDF) membranes (Millipore). After the membranes were infiltrated in 5\% non-fat milk solution in washing buffer (20 mM Tris- $\mathrm{HCl}, \mathrm{pH} 8.0 ; 150 \mathrm{mM} \mathrm{NaCl}$; and $0.05 \%$ Tween-20) for $2 \mathrm{~h}$, they were incubated overnight at $4^{\circ} \mathrm{C}$ with different primary antibodies for different target proteins: mouse anti- $\beta$-actin, rabbit polyclonal anti-Bax, and anti-Bcl-2 (Abcam, England). Membranes were washed with washing buffer three times, followed by incubation with antirabbit and anti-mouse secondary antibodies (Abcam, England) at room temperature for 1 h. Immunoreactive protein bands were detected using an enhanced chemiluminescent kit (Thermo Scientific Pierce ECL, USA) and were photographed using a ChemiScope $2950 \mathrm{MI}$ (Clinx Science Instruments, China).

\section{Real-time polymerase chain reaction}

The gene expressions of $\beta$-actin, Bax, and Bcl-2 in HeLa cells were detected using real-time polymerase chain reaction analysis. HeLa cells $\left(5 \times 10^{5}\right)$ were treated with $3,4,5$, and $6 \mathrm{mg} / \mathrm{mL} \mathrm{BBE}$ for $36 \mathrm{~h}$. The total RNA was extracted from the treated cells using RNAiso Plus (TaKaRa) according to manufacturer instructions. The quality of RNA samples was determined by running on a $1 \%$ agarose gel. DNase-I (Fermentas) was used to remove DNA contamination.

cDNA was synthesized by reverse transcription by using a PrimeScript ${ }^{\circledR} \mathrm{RT}$ reagent kit perfect real time (TaKaRa) in a $20-\mu \mathrm{Ll}$ reaction mixture containing $4 \mu \mathrm{L} 5 \mathrm{x}$ PrimeScript buffer, $1 \mu \mathrm{L}$ PrimeScript ${ }^{\circledR}$ RT enzyme mix, $1 \mu \mathrm{L}$ oligo dT primer, and $14 \mu \mathrm{L}$ total RNA having $1 \mu \mathrm{g}$ RNA. The reaction conditions were $37^{\circ} \mathrm{C}$ for $15 \mathrm{~min}$ and $85^{\circ} \mathrm{C}$ for $5 \mathrm{~s}$. The product of reverse transcription was stored at $-80^{\circ} \mathrm{C}$.

Real-time polymerase chain reaction was performed using an iCycler iQ2 real-time polymerase chain reaction detection system (Bio-Rad) with SYBR green dye bound to the double-strand DNA at the end of each elongation cycle (TaKaRa). The primers for $\beta$-actin, $B c l-2$, and Bax were as follows:

$\beta$-actin-F: 5'-CAGGGCGTGATGGTGGGCATGG-3'; $\beta$-actin-R: 5'-TAGCACAG CCTGGATAGCAACGTAC-3'; Bcl-2-F: 5'-GGAGAACGGGGTACGATAA-3'; Bcl-2-R: 5'-CCACCGAACTCAAAGAAGG-3'; Bax-F: 5'-GAGCAGGGCGAATGGG-3'; Bax-R: 5'-TGGTGAGTGAGGCGGTGA-3'; Real-time polymerase chain reaction was conducted in $20-\mu \mathrm{L}$ reactions containing $10 \mu \mathrm{L}$ SYBR Premix Ex Taq ${ }^{\mathrm{TM}} \mathrm{II}, 10 \mu \mathrm{M} 0.8 \mu \mathrm{L}$ of each primer, $2.0 \mu \mathrm{L}$ DNA template, and $6.4 \mu \mathrm{L} \mathrm{dH}_{2} \mathrm{O}$. The parameters for real-time polymerase chain reaction were as follows: stage $1,95^{\circ} \mathrm{C}$ for $30 \mathrm{~s}$; stage 2,40 cycles of $95^{\circ} \mathrm{C}$ for $5 \mathrm{~s}, 60^{\circ} \mathrm{C}$ for $20 \mathrm{~s}$; 
stage $3,95^{\circ} \mathrm{C}$ for $0 \mathrm{~s}, 65^{\circ} \mathrm{C}$ for $15 \mathrm{~s}, 95^{\circ} \mathrm{C}$ for $0 \mathrm{~s}$. Gene expression levels in HeLa cells were calculated using the comparative $2^{-\Delta \Delta \mathrm{CT}}$ method (Livak and Schmittgen, 2001).

\section{RESULTS}

\section{Cytotoxicity of BBE}

The BBE cytotoxicity in HeLa cells in a time- and concentration-dependent manner (Figure 1). At a dose of $2 \mathrm{mg} / \mathrm{mL} \mathrm{BBE}, 28 \%$ inhibition was noted after 24-h treatment, which increased to $94 \%$ after $72-\mathrm{h}$ treatment. When the dose was increased to $6 \mathrm{mg} / \mathrm{mL}$, the inhibition rate was $40 \%$ after 18 -h treatment. When HeLa cells were treated for $48 \mathrm{~h}$, the $50 \%$ inhibition concentration $\left(\mathrm{IC}_{50}\right)$ value of the $\mathrm{BBE}$ was $1.564 \mathrm{mg} / \mathrm{mL}$. These results suggested that the $\mathrm{BBE}$ could remarkably inhibit the growth of HeLa cells in vitro.

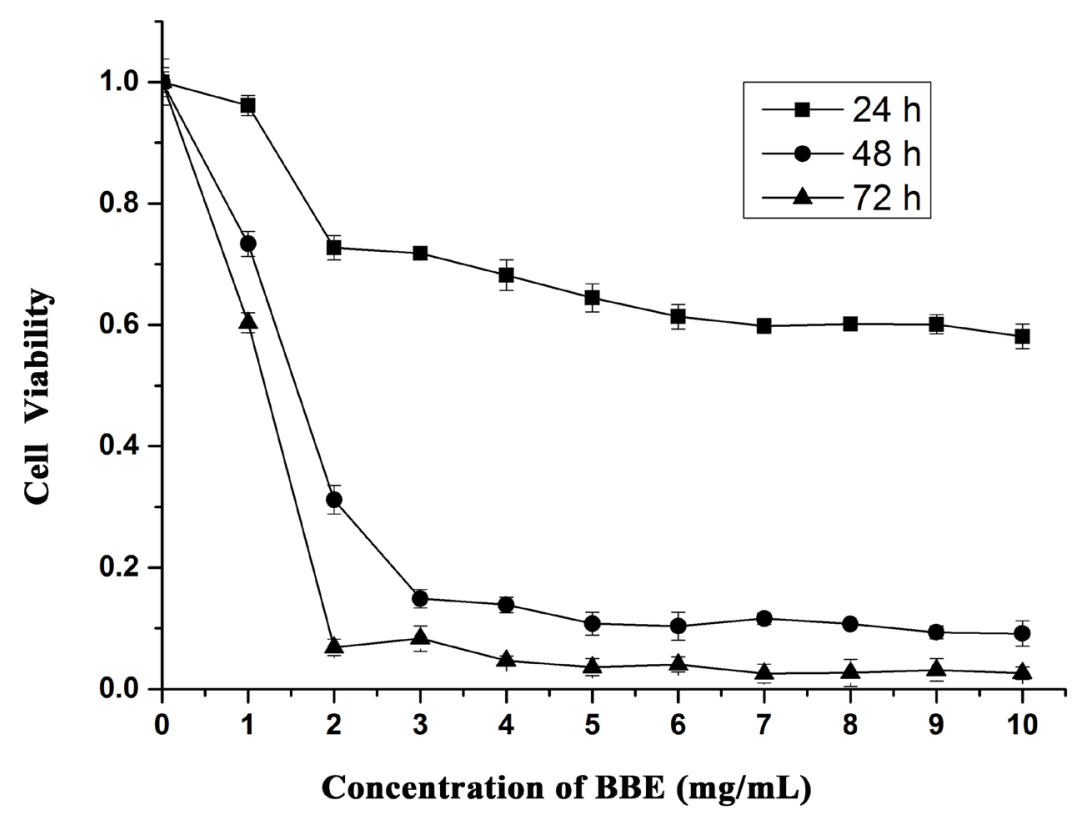

Figure 1. Effect of the Bombyx batryticatus ethanol (BBE) extract on the proliferation of HeLa cells. HeLa cells were treated with $1.0-10.0 \mathrm{mg} / \mathrm{mL}$ BBE for 24,48 , and $72 \mathrm{~h}$. The results were expressed as an average of three replicates \pm standard deviation (SD).

\section{Morphological assessment of BBE-treated cells}

There were significant changes in cell morphology after treatment with increasing concentrations of BBE for $24 \mathrm{~h}$ (Figure 2). The majority of HeLa cells were severely distorted, grew slowly, and became round in shape after incubation with the BBE. The untreated cells showed normal, healthy growth as revealed by the clear skeletons observed by inverted microscopy (Figure 2A). 

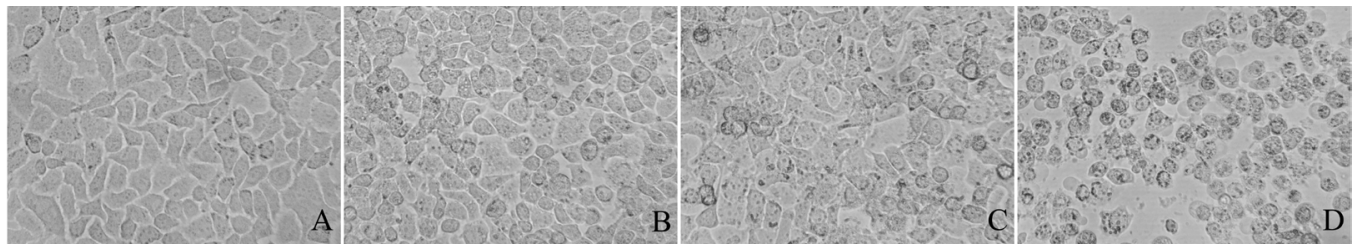

Figure 2. Morphologic changes in cells observed under an inverted microscope (25X). HeLa cells treated with the Bombyx batryticatus ethanol (BBE) extract showed a round morphology and shrinkage. A. Control, B. $1 \mathrm{mg} / \mathrm{mL}$, C. $3 \mathrm{mg} / \mathrm{mL}$, D. $5 \mathrm{mg} / \mathrm{mL}$.

\section{BBE-induced DNA fragmentation in HeLa cells}

Remarkable DNA fragmentation was noted in HeLa cells treated with $7 \mathrm{mg} / \mathrm{mL}$ BBE for $36 \mathrm{~h}$. BBE on the other hand, the control cells did not exhibit any DNA fragmentation (Figure 3).

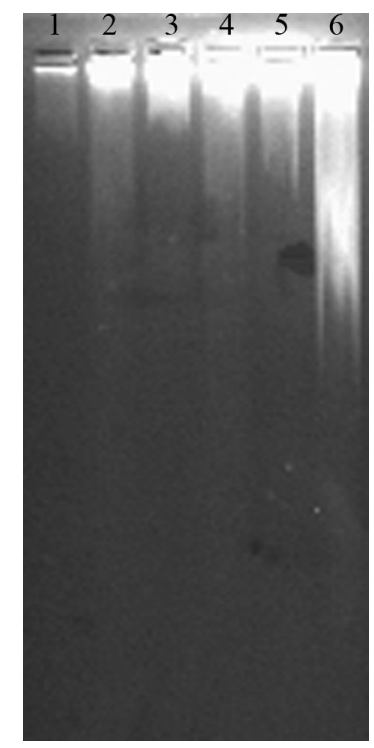

Figure 3. DNA fragmentation caused by treatment of HeLa cells with the Bombyx batryticatus ethanol (BBE) extract for $36 \mathrm{~h}$. Lanes 1 to $6=0$ (control), 3, 4, 5, 6, and $7 \mathrm{mg} / \mathrm{mL}$, respectively.

\section{BBE-induced gene expression profiles}

The mechanisms of apoptotic activity induced by the BBE were determined by analyzing the mRNA and protein expression levels of $B c l-2$ and Bax; $\beta$-actin was used as a reference gene. The expression of Bax protein remarkably increased whereas that of Bc1-2 protein was decreased after treatment of HeLa cells with the BBE for $36 \mathrm{~h}$ (Figure 4). Real timepolymerase chain reaction analysis indicated that the transcription level of $B c l-2$ decreased markedly after treatment with different concentrations of BBE, whereas that of Bax increased only slightly. The ratio of $\mathrm{Bax} / \mathrm{Bcl}-2$ also increased after treatment with the BBE (Figure 5). 


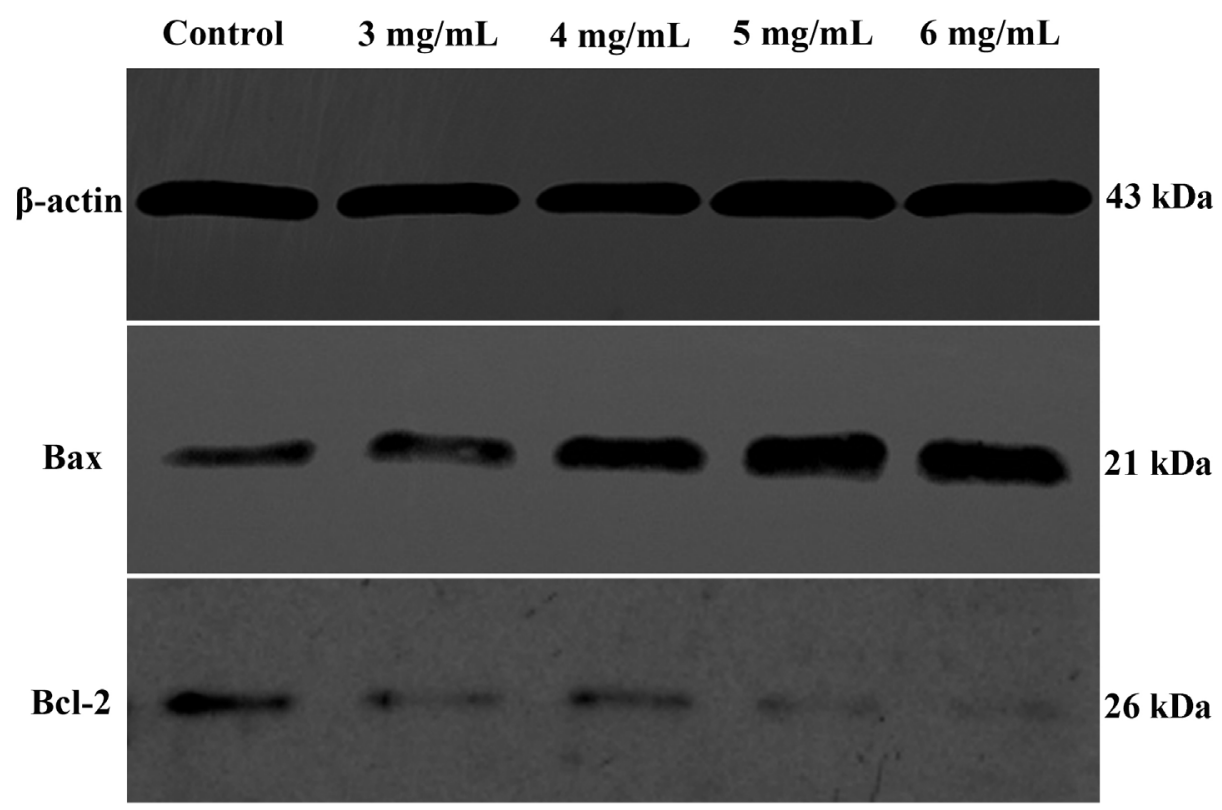

Figure 4. Effects of the Bombyx batryticatus ethanol (BBE) extract on $\beta$-actin, Bcl-2, and Bax protein expressions in HeLa cells. HeLa cells were treated with 3, 4, 5, and $6 \mathrm{mg} / \mathrm{mL} \mathrm{BBE}$ for $36 \mathrm{~h}$.

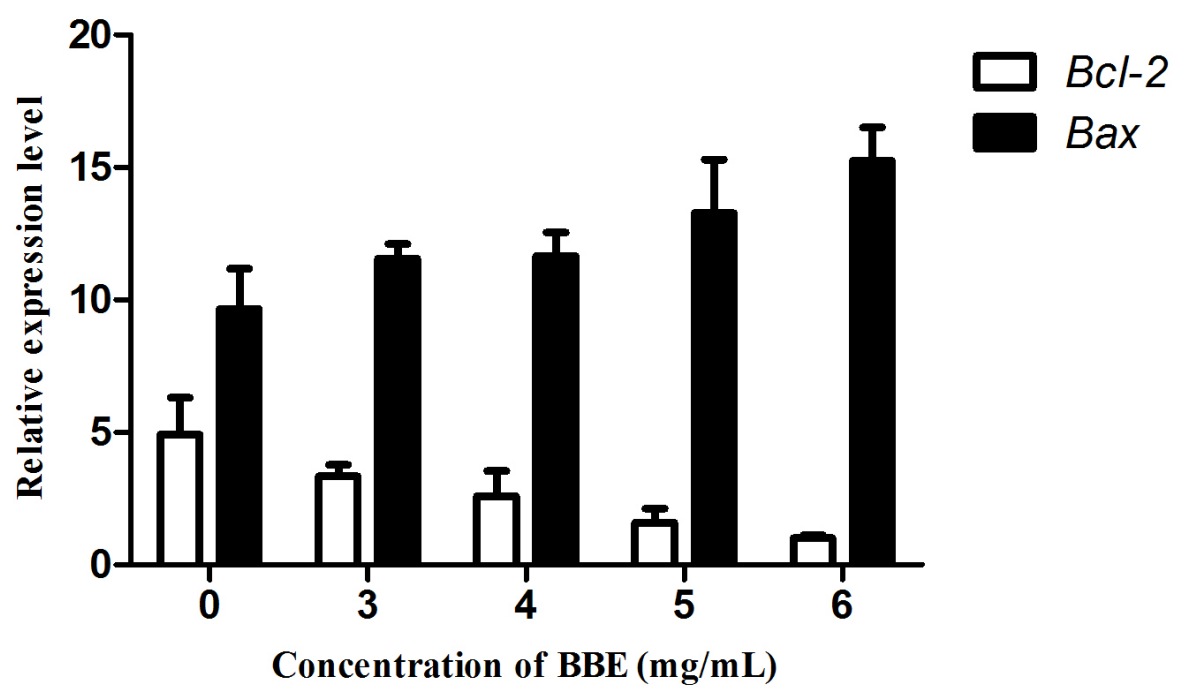

Figure 5. Relative expression levels of $B c l-2$ and $B a x$ in HeLa cells. HeLa cells were treated with 3, 4, 5, and $6 \mathrm{mg} /$ $\mathrm{mL}$ Bombyx batryticatus ethanol (BBE) extract for $36 \mathrm{~h}$. Results were expressed as an average of three replicates \pm standard deviation (SD). $\beta$-actin was used as an internal reference gene. The relative expression was calculated on the basis of the value of the lowest expression (expression levels of $B c l-2$ at $6 \mathrm{mg} / \mathrm{mL}$ ), which was ascribed an arbitrary value of 1 . 


\section{DISCUSSION}

In this study, we analyzed the effects of BBE on the proliferation and apoptosis of HeLa cells in vitro. BBE remarkably inhibited the growth and induced apoptosis of HeLa cells. The growth inhibition effect of BBE in HeLa cells was evident by both cell morphological assessment and MTT analyses. Treatment with BBE caused severe distortion of the cells, and cell proliferation was inhibited. Furthermore, DNA fragmentation assay suggested the occurrence of chromosomal DNA fragmentation.

Apoptosis is a form of physiological cell death that is essential for cell tissue development and homeostasis (Vaux and Korsmeyer, 1999). After an apoptotic death stimulus is received, cells show typical apoptotic features characterized by chromatin condensation, cytoplasmic shrinkage, plasma membrane blebbing, caspase activation, membrane lipid rearrangement, and DNA fragmentation via the formation of "apoptotic bodies" (Kerr et al., 1972; Wyllie et al., 1980; Jacobson et al., 1997; Earnshaw et al., 1999). Apoptosis and its related signaling pathways have a remarkable impact on the progression of cancer (Lowe and Lin, 2000). Therefore, induction of apoptosis is a highly desirable goal of cancer control strategies (Reed and Pellecchia, 2005).

Apoptosis is a complex biological process that involves two main pathways, namely, the extrinsic and intrinsic apoptosis signaling pathways (Budihardjo et al., 1999; Chen and Wang, 2003; Twomey and McCarthy, 2005). The extrinsic or cytoplasmic pathway is triggered via the Fas death receptor, a member of the tumor necrosis factor (TNF) receptor superfamily (Hu et al., 2009). The intrinsic or mitochondrial pathway leads to the release of cytochrome c from the mitochondria and the activation of the death signal after stimulation (Hu et al., 2009). The intrinsic pathway is regulated by the Bcl-2 family proteins, which play an important role in cell apoptosis (Vander Heiden and Thompson, 1999). The Bcl-2 family includes proapoptotic members such as bax, bak, bad, bcl-xS, bid, bik, bim, and hrk, and antiapoptotic members such as bcl-2, bcl-xL, bcl-w, bfl-1, and mcl-1 (Tamm et al., 2001). The antiapoptotic protein Bcl-2 acts as a repressor (Pattingre et al., 2005), whereas the proapoptotic protein Bax acts as a promoter (Kawai-Yamada et al., 2005) of apoptosis. Interestingly, the effects on apoptosis are more dependent on the ratio between $\mathrm{Bcl}-2$ and $\mathrm{Bax}$ than on the quantity of $\mathrm{Bcl}-2$ alone (Reed, 1997; Pettersson et al., 2002; Heimlich et al., 2004). The intracellular Bax/Bcl-2 ratio is elevated with an increased apoptotic cell death (Zha and Reed, 1997). Therefore, to further understand the molecular mechanism of apoptosis induced by the BBE, we detected the changes in protein and mRNA expression levels of Bcl-2 and Bax using Western blot analysis and realtime polymerase chain reaction analysis, respectively. The results showed that the expression of Bcl-2 was remarkably decreased whereas that of Bax was slightly increased at both the protein and mRNA levels, and the ratio of $\mathrm{Bax} / \mathrm{Bcl}-2$ increased after treatment with different concentrations of the BBE. Previous studies (Zha and Reed, 1997; Reed, 1997; Pettersson et al., 2002; Heimlich et al., 2004) have suggested one possible mechanism for the BBE-induced apoptosis: gene expression was regulated by upregulating $B a x$ and downregulating $B c l-2$.

\section{CONCLUSION}

In summary, we showed that the BBE induces significant cytotoxicity against $\mathrm{HeLa}$ cells. The BBE inhibits growth and induces apoptosis of HeLa cells by regulating the Bcl-2and Bax-mediated apoptotic pathways. The findings of this study indicate that this insect prod- 
uct can be used as a novel anticancer agent and reveal the potential value of insects used in traditional medicines, which might be an underappreciated source of pharmacological substances.

\section{ACKNOWLEDGMENTS}

Research supported by the National Natural Science Foundation of China (\# 31270691, \#31170609) and Program for Changjiang Scholars and Innovative Research Team in University (\#IRT1035). The authors sincerely thank J.L. Koprowski for editing the manuscript for language.

\section{REFERENCES}

Budihardjo I, Oliver H, Lutter M, Luo X, et al. (1999). Biochemical pathways of caspase activation during apoptosis. Annu. Rev. Cell Dev. Biol. 15: 269-290.

Cao J, Yu H, Zhang RF, Wang F, et al. (2012). Toxicity and alkaline phosphatase activity inhibition of the extracts form Bombyx batryticatus against Helicowerpa armigera. J. Northw. For. Univ. 27: 101-104.

Chen M and Wang J (2003). Initiator caspases in apoptosis signaling pathways. Apoptosis 7: 313-319.

Chou CC, Pan SL, Teng CM and Guh JH (2003). Pharmacological evaluation of several major ingredients of Chinese herbalmedicines in human hepatoma Hep3B cells. Eur. J. Pharm. Sci. 19: 403-412.

Earnshaw WC, Martins LM and Kaufmann SH (1999). Mammalian caspases: structure, activation, substrates, and functions during apoptosis. Annu. Rev. Biochem. 68: 383-424.

Fokunang CN, Ndikum V, Tabi OY, Jiofack RB, et al. (2011).Traditional medicine: past, present and future research and development prospects and integration in the national health system of Cameroon. Afr. J. Tradit. Complement. Altern. Med. 8: 284-295.

Heimlich G, McKinnon AD, Bernardo K, Brdiczka D, et al. (2004). Bax-induced cytochrome c release from mitochondria depends on alphahelices-5 and -6. Biochem. J. 378: 247-255.

$\mathrm{Hu}$ YW, Liu CY, Du CM, Zhang J, et al. (2009). Induction of apoptosis in human hepatocarcinoma SMMC-7721 cells in vitro by flavonoids from Astragalus complanatus. J. Ethnopharmacol. 123: 293-301.

Jacobson MD, Weil M and Raff MC (1997). Programmed cell death in animal development. Cell 88: 347-354.

Kawai-Yamada M, Saito Y, Jin L, Ogawa T, et al. (2005). A novel Arabidopsis gene causes Bax-like lethality in Saccharomyces cerevisiae. J. Biol. Chem. 280: 39468-39473.

Kerr JF, Wyllie AH and Currie AR (1972). Apoptosis: a basic biological phenomenon with wide-ranging implications in tissue kinetics. Br. J. Cancer 26: 239-257.

Li WY, Chan SW, Guo DJ, Chung MK, et al. (2009).Water extract of Rheum officinale Baill. induces apoptosis in human lung adenocarcinoma A549 and human breast cancer MCF-7 cell lines. J. Ethnopharmacol.124: 251-256.

Li XK, Motwani M, Tong W, Bornmann W, et al. (2000). Huanglian, a Chinese herbal extract, inhibits cell growth by suppressing the expression of Cyclin $\mathrm{B} 1$ and inhibiting CDC2 Kinase activity in human cancer cells. Mol. Pharmacol. 58: $1287-1293$.

Livak KJ and Schmittgen TD (2001). Analysis of relative gene expression data using real-time quantitative PCR and the $2^{-\Delta \Delta C T}$ method. Methods 25: 402-408.

Lowe SW and Lin AW (2000). Apoptosis in cancer. Carcinogenesis 21: 485-495.

Pattingre S, Tassa A, Qu X, Garuti R, et al. (2005). Bcl-2 antiapoptotic proteins inhibit Beclin 1-dependent autophagy. Cell 122: 927-939.

Pettersson F, Dalgleish AG, Bissonnette RP and Colston KW (2002). Retinoids cause apoptosis in pancreatic cancer cells via activation of RAR-gamma and altered expression of Bcl-2/Bax. Br. J. Cancer 87: 555-561.

Reed JC (1997). Bcl-2 family proteins: regulators of apoptosis and chemoresistance in hematologic malignancies. Semin. Hematol. 34: 9-19.

Reed JC and Pellecchia M (2005). Apoptosis-based therapies for hematologic malignancies. Blood 106: 408-418.

Tamm I, Schriever F and Dorken B (2001). Apoptosis: implications of basic research for clinical oncology. Lancet Oncol. 2: $33-42$.

Twomey C and McCarthy JV (2005). Pathways of apoptosis and importance in development. J. Cell. Mol. Med. 9: 345359.

Vander Heiden MG and Thompson CB (1999). Bcl-2 proteins: regulators of apoptosis or of mitochondrial homeostasis. 
Nat. Cell Biol. 1: E209-216.

Vaux DL and Korsmeyer SJ (1999). Cell death in development. Cell 96: 245-254.

Wyllie AH, Kerr JF and Currie AR (1980). Cell death: the significance of apoptosis. Inter. Rev. Cytol. 68: 251-306.

Zha H and Reed JC (1997). Heterodimerization-independent functions of cell death regulatory proteins Bax and Bcl-2 in yeast and mammalian cells. J. Biol. Chem. 272: 31482-31488. 